\title{
Energy-momentum in the viscous Kasner-type universe in teleparallel gravity
}

\author{
Mustafa Salti
}

Published online: 11 January 2008

(C) Springer Science+Business Media B.V. 2008

Erratum to: Astrophys Space Sci (2005) 299(2):159-166

DOI 10.1007/s10509-005-5159-7

After investigation and at the request of the President of the Middle East Technical University (METU), Ankara, Turkey, the Editors of Astrophysics and Space Science have decided to retract this paper due to extensive plagiarism of work by others.

The online version of the original article can be found at: http://dx.doi.org/10.1007/s10509-005-5159-7.

M. Salti $(\bowtie)$

Department of Physics, Faculty of Art and Science, Mersin University, 33343 Ciftlikkoy, Mersin, Turkey

e-mail: musts6@yahoo.com 